\title{
In-Vivo Antidiabetic Activity and Safety Profile of Fruits Extract and Fraction of Solanum Terminale Forsk (Solanaceae)
}

\author{
Rajabu M. Kingo ${ }^{1,2^{*}}$, Sheila M. Maregesi ${ }^{2}$, Abdul W. Kidukuli ${ }^{2}$, Amos R. Mwakigonja ${ }^{3}$ \\ ${ }^{1}$ Department of Biomedical Sciences, College of Health Sciences, The University of Dodoma, Tanzania. \\ ${ }^{2}$ Department of Pharmacognosy, School of Pharmacy, Muhimbili University of Health and Allied Sciences, Dar \\ Es Salaam, Tanzania \\ ${ }^{3}$ Department of Pathology - School of Medicine, Muhimbili University of Health and Allied Sciences, Dar Es \\ Salaam, Tanzania
}

*Corresponding Author: Rajabu M. Kingo, Department of Biomedical Sciences, College of Health Sciences, The University of Dodoma, Tanzania.

\begin{abstract}
:
Background: Majority of people opt the use of traditional means of treatment especially medicinal plants on the notion of being safe since they are naturally derived.

Objective: The study aimed at evaluation of the antidiabetic efficacy of extract and fraction and safety profile of Solanum terminale fruits extract in mice.
\end{abstract}

Methods: Mice were induced diabetes by intraperitoneal injection of freshly prepared alloxan monohydrate $170 \mathrm{mg} / \mathrm{kg}$ BW.The diabetic mice were treated once daily with crude extract and methanol fraction (100 $m g / k g ~ B W)$ for 20 days, and FBG were recorded on day 1, 5, 10, 15 and 20. The effects of the extract and fraction on FBG levels of the diabetic mice were evaluated. OECD guidelines were used in assessing the acute oral toxicity of S. terminale fruits extract by single dose of crude extract at $2000 \mathrm{mg} / \mathrm{kg} \mathrm{BW}$. Mice were observed for 14 days for their mortality, behavioral and other changes. Before sacrifice, weight of mice and the visceral organs were recorded, and sent for histological evaluations. Results were expressed as mean \pm $S D$, analysed by independent student's t-test, $p<0.05$ was considered as significant level. Ethical clearance was sought from MUHAS, IRB and animal care followed the EEC Directive of 1986; 86/609/EEC.

Results: Crude ethanolic fruit extract of $S$. terminale and methanolic fraction demonstrated clinical and statistical significant blood glucose lowering efficacy in mice ( $p<0.05)$. Neither death nor abnormal changes in behavioral features in tested mice observed at $2000 \mathrm{mg} / \mathrm{kg} \mathrm{BW}$ of S. terminale crude ethanolic fruit extract. The histological analysis demonstrated some organ derangements at $2000 \mathrm{mg} / \mathrm{kg} \mathrm{BW}$ of S. terminale crude ethanolic fruit extract.

Conclusion: The fruits are nearly safe for use in low doses/consumption. Further work is needed including more antidiabetic screening exhausting other techniques, further toxicological studies, identification of the active compounds, and standardization/formulation of $S$. terminale fruits products.

Keywords: terminale, acute oral toxicity, diabetes mellitus, $L D_{50}$.

Abbreviations

$\begin{array}{lll}\text { BW } & - & \text { Body weight } \\ \text { FBG } & - & \text { Fasting Blood Glucose } \\ \text { HP } & - & \text { High Power } \\ \text { IRB } & - & \text { Institutional Review Board } \\ \text { LD } & - & \text { Lethal Dose } \\ \text { MUHAS } & - & \text { Muhimbili University of Health and Allied Sciences } \\ \text { OECD } & - & \text { Organization for Economic Co-operation and Development } \\ \text { OGTT } & - & \text { Oral Glucose Tolerance Test } \\ \text { SD } & - & \text { Standard Deviation } \\ \text { TLC } & - & \text { Thin Layer Chromatography }\end{array}$




\section{INTRODUCTION}

Diabetes mellitus is a disorder occurs due to the alterations in carbohydrate, lipid and protein metabolism clinically observed by hyperglycaemia. About $1.3 \%$ of the world population is estimated to suffer the disease and it is among of the five killer diseases in the world [1]. Insulin resistance or islet $\beta$-cells of Langerhans destruction or both effects are the pathophysiological processes leading to the development of the disease where by patients usually presents with polyuria, polydipsia, polyphagia, weight loss and fatigue [2].

Lifestyle modification and the use of insulin or oral hypoglycemic drugs is the conventional mode of diabetes treatment.However, side effects and costs associated with these medicines made traditional means of treatment using plants to be highly favoured by the majority, since they are readily accessible, affordable and believed to be free from side effects [1]. On ideal situation, not all plants are safe, as there are some plants reported as potential toxic and elicit various noxious effects on the user [3].

Various plants being used traditionally have their extracts been proven scientifically to have the antidiabetic activity $[4,5]$. Solanum terminalefruits are used traditionally for diabetes management and on the previous study it has demonstrated hypoglycaemic efficacy by lowering the blood glucose levels in OGTT tested mice at $100 \mathrm{mg} / \mathrm{kg}$ body weight [6]. The aim of this study was to investigate the antidiabetic effect of $S$. terminale crude ethanolic fruit extract and its methanolic fraction in alloxan induced white albino mice as well as assessing its safety profile through acute oral toxicity testing.

\section{Materials AND Methods}

\subsection{Collection of Medicinal Plant}

Fruits of S. terminale were collected from Lushoto, North Eastern highlands of Tanzania in November 2018. The plant then identified by Mr. Haji Selemani, a senior botanist and the leaves voucher specimens stored at the Pharmacognosy Department, MUHAS.

\subsection{Materials, Chemicals and Reagents}

Glucometer and testing strips (GlucoPlus Inc., Canada), $1 \mathrm{ml}$ syringes, gloves, masks, aluminium foils, normal saline, cotton wools, distilled water, Methylated spirits (local pharmacies, Dar es salaam, Tanzania), where by Chlorpropamide tablets (Dibonis ${ }^{\circledR}$, Cosmos Ltd, Nairobi, Kenya) and 95\% Ethanol (Tanzania Oxygen Ltd), Methanol (Fisher Chemical, UK), Chloroform, Hydrochloric Acid, Concentrated Sulphuric Acid, (MERCK KGaA group, Darmstadt, Germany), were used in the study.

\subsection{Extraction and Fractionation}

$800 \mathrm{~g}$ of fresh pounded S. terminale fruits was exhaustively extracted with $95 \%$ ethanol by maceration. The extract was dried using the rotary evaporator (BüchiLabortechnik, Flawil, Switzerland) at $40^{\circ}$ temperature to reduce the solvent to the maximum. Then, to obtain dry extract, was subjected to freeze drying (Edwards High Vacuum International Crawley, Sussex, England). In fractionation, 20g of crude ethanolic extract was adsorbed on $40 \mathrm{~g}$ of silica gel and packed on a column. To obtain the fraction, Methanol was eluted under gravity. Elution was exhaustive checked by TLC spotting.

\subsection{Selection of Animals for Antidiabetic Testing}

Experiments were performed using healthy young adult male albino mice, weighing 20-32 g, 8 to 12 weeks old. The mice were housed in metal cages; allowed to feed ad libitum and lighting was controlled to supply $12 \mathrm{~h}$ of light and $12 \mathrm{~h}$ of dark for each 24 -h period. Each cage was identified by test substance and dose. All mice were acclimatized for $4-7$ days prior to the test.

The mice were randomly divided into groups each containing 8 mice. Each mouse in each group was identified by the markings using permanent marker (colours) on various body parts for easy identification of the received dose.

\subsection{Induction of Diabetes}

Prior to the induction of diabetes, mice fasted for 14 hours followed by measuring their weight and blood sample collection from the tails by venipuncture to determine the fasting blood glucose (FBG). 
Experimental mice were exposed to single intraperitoneal administration of freshly prepared alloxan monohydrate in normal saline at a dose of $170 \mathrm{mg} / \mathrm{kg}$ body weight $[7,8]$. Within 30 minutes of alloxan administration, the mice were allowed to feed on standard food pellets and water ad libitum. Thereafter, the mice were kept for 3 days (72 hours) [9] and the blood glucose levels were determined. Alloxan treated mice with more than $75 \%$ increase in blood glucose levels using the formula below and/or with FBG $11.1 \mathrm{mmol} / \mathrm{l}$ were considered diabetic hence selected for the study.

$\%$ increase in FBG $=\frac{F B G \text { after alloxan }-F B G \text { before alloxan }}{F B G \text { before alloxan }} \times 100$

Whereby;

FBG before alloxan = Initial FBG before alloxan administration

FBG after alloxan $=$ FBG recorded after 72 hours of alloxan administration

\subsection{Administration of Extracts and Hypoglycemic Testing}

Diabetic mice were intragastrically administered with test extract and fractions at the dose of 100 $\mathrm{mg} / \mathrm{kg}$ BW once daily. Treatment commenced on third-day (72 hours) post induction of diabetes considered as the first day of treatment and the study continued for 20 days. Blood glucose levels were measured by using a glucometer and were recorded on day 1, 5, 10, 15 and 20 of treatment.

Diabetic mice were randomly divided into groups each with 8 mice and treated as follows;

Group 1: Diabetic negative control - Diabetic mice administered with 5\% 1ml/kg ethanol

Group 2: Diabetic mice administered with the crude ethanolic extract at the dose of $100 \mathrm{mg} / \mathrm{kg} \mathrm{BW}$.

Group 3: Diabetic mice administered with the methanol fraction at the dose of $100 \mathrm{mg} / \mathrm{kg} \mathrm{BW}$.

Group 4: Diabetic positive control - Diabetic mice administered with chlorpropamide $100 \mathrm{mg} / \mathrm{kg}$ BW.

\subsection{Determination of Acute Oral Toxicity}

Acute oral testing of the albino mice followed the procedures stipulated by the OECD guidelines 423 [10]. Animals were fasted with allowed access to water for 3-4 hours prior to the experiment.

Animals for determination of acute oral toxicity were grouped to involve each group with 4 animals; started with the dose of $2000 \mathrm{mg} / \mathrm{kg}$ abiding with procedures from the OECD guideline 423 , Annexure $2 c$ [10], which recommended that the starting dose level should be that which is most likely to produce mortality in some of the dosed animals. The same procedure was followed for vehicle treated control group.

A single dose of extract was given and observed for 14 days for their behavioral (tremors, convulsions, salivation, diarrhoea, lethargy, sleep), respiratory changes as well as mortality.

Both the groups were observed closely for any toxic effect within first6 hours and then at regular intervals for a total period of 14 days. Weights of animals were monitored and at the end of study, animals were weighed. Vital organs were excised after killing mice by chloroform inhalation; weight of organs was noted, organ to body weight index calculated and then organs preserved in $40 \%$ formalin and sent for histopathological evaluation.

The formula used to calculate percentage organ to body weight index was;

organ to body weight index $(\%)=\frac{\text { organ weight }(g)}{\text { body weight }(g)} \times 100$

\subsection{Histopathological Evaluation}

Animals were humanely sacrificed and the vital organs (kidney, lungs, heart, liver, spleen and intestines) isolated, weighed and examined for macroscopic changes and/or development of any lesions [11], then stored in $40 \%$ formalin. Features of both treated and control groups were compared and then histologically evaluated by the Department of Pathology - MUHAS.

Tissues from the mice were fixed for 24 hours in neutral well-buffered (40\%) formalin, embedded in paraffin and sections $(5 \mu \mathrm{m})$ mounted on SuperFrost slides (Menzel GmbH \&CoKG, Braunschweig, 
Germany). These were then deparaffinized, rehydrated and stained with haematoxylin and eosin (H\&E). Histological evaluation and photomicrography was performed by the Histopathologist using an Olympus (CX31RBSF Model) light microscope equipped with a digital camera (Olympus Corporation, Tokyo, Japan). Tissue toxicity (damage) was evaluated under the microscope on 7 lowpower fields (x10 magnification) as well as on their high-power fields (x40 magnification) while taking pictures [11,12]. Picture processing and printing was performed using Adobe Photoshop 7.0 (Adobe Systems Incorporated, San Jose, CA, USA).

\subsection{Statistical Analysis}

Results expressed as mean $\pm \mathrm{SD}$, and the level of statistical significance was determined using independent student t-test, when the difference between the means of two populations was considered (each against the negative control). $p<0.05$ was considered as a significant level.

\subsection{Ethical Clearance}

The ethical clearance to conduct this study was granted from the Institutional Review Board, MUHAS, with Ref no. DA.287/298/01A/, and the use of mice followed internationally accepted principles for laboratory animal use and care stipulated in EEC Directive of 1986 [13].

After completion of the study, mice were humanely killed by inhalation of chloroform abiding to the international accepted principles for laboratory care and use of animals [14] and disposed at MNH incinerator.

\section{RESULTS AND DISCUSSIONS}

\subsection{Alloxan Model}

Day 1 was 72 hours after alloxanization of mice to induce diabetes. It was observed with the steep elevation of FBG levels of above 75\% (Table 1). Arikaet al., (2016)reported a four to five fold elevation in blood glucose levels relative to the normal control mice after alloxanization [2]. Increased rate of urination (polyuria), increased rate of water drinking associated with much thirsty (polydipsia), increased amount of food consumption (polyphagia) and weakness were also observed in mice.

The overall trend of the mean FBG levels for the whole treatment period as presented in the Table 1. The mean blood glucose levels of the crude extract, methanolic fraction and chlorpropamide treated diabetic mice decreased from day 5 of treatment in contrast to the $5 \%$ ethanol treated diabetic mice. After 20 days, the reduction of the mean blood glucose levels for all groups were chlorpropamide $>$ crude extract > methanolic fraction > 5\% ethanol (see Figure 1). At this dose of $100 \mathrm{mg} / \mathrm{kg} \mathrm{BW}$, chlorpropamide managed to reduce $70 \%$ of the increased FBGs, where by the S. terminale ethanolic crude extract reduced nearly $60 \%$ and the methanolic fraction by $53 \%$ (Figure 2).

The crude ethanolic extract and methanolic fraction have demonstrated a comparable activity with the chlorpropamide, all at a dose of $100 \mathrm{mg} / \mathrm{kg} \mathrm{BW}$, however, statistically chlorpropamide and crude ethanolic extract managed to significantly lower the FBG $(p<0.05)$ from day 5 of treatment. Some studies, for example;Moshi et al., 1997reported the ability of the Phyllanthus amarus extracts in clearing the glucose load but did not significantly lower the FBG[15].

As reported on the previous study [6], the $S$. terminalecrude ethanolic extract and methanolic fraction has also demonstrated clinical and statistical significance $(p<0.05)$ in alloxan induced diabetic mice, implies the efficacy of the fruits in the management of diabetes.

Minimal reduction of body weight were observed; $5 \%$ ethanol $(4.63 \mathrm{~g})$, crude extract $(1.87 \mathrm{~g})$, methanolic fraction $(1.5 \mathrm{~g})$ and chlorpropamide $(2.38 \mathrm{~g})$ from day 0 to day 20 of treatment. The animals slightly did not lose body weight with the crude extract and methanolic fraction as compared with the vehicle-treated group (Table 2), which signifies the valuable effect of the fruits in preventing further loss of body weight as seen with an aqueous extract of Pleurotuspulmonarius[16].

Table1. Mean FBG (mmol/l) of Alloxan Treated Diabetic Mice

\begin{tabular}{|l|l|l|l|l|}
\hline \multirow{2}{*}{$\begin{array}{l}\text { Time } \\
\text { (Days) }\end{array}$} & \multicolumn{4}{|l|}{ Mean Blood Glucose Levels $(\mathbf{m m o l} / \mathrm{l}) \pm$ S.D, $\mathbf{n}=\mathbf{8}$} \\
\cline { 2 - 5 } & Controls & Extract and Fractions at a dose 100mg/kg body weight \\
\cline { 2 - 4 } & Negative & Positive & Crude Extract & MeOH Fraction \\
\hline
\end{tabular}


In-Vivo Antidiabetic Activity and Safety Profile of Fruits Extract and Fraction of Solanum Terminale Forsk (Solanaceae)

\begin{tabular}{|l|l|l|l|l|}
\hline $\mathbf{0}$ & $2.88 \pm 0.84$ & $3.79 \pm 1.63$ & $3.64 \pm 1.17$ & $4.2 \pm 1.34$ \\
\hline $\mathbf{1}$ & $14.20 \pm 5.53$ & $16.6 \pm 3.99$ & $14.29 \pm 2.35$ & $16.29 \pm 3.09$ \\
\hline $\mathbf{5}$ & $14.78 \pm 7.42$ & $9.14 \pm 4.51^{*}$ & $9.23 \pm 2.89^{*}$ & $11.83 \pm 5.02$ \\
\hline $\mathbf{1 0}$ & $12.10 \pm 6.96$ & $8.16 \pm 3.51^{*}$ & $8.04 \pm 2.52^{*}$ & $8.55 \pm 3.22^{*}$ \\
\hline $\mathbf{1 5}$ & $10.18 \pm 4.40$ & $6.5 \pm 4.34^{*}$ & $6.36 \pm 2.58^{*}$ & $8.23 \pm 3.44^{*}$ \\
\hline $\mathbf{2 0}$ & $9.18 \pm 4.38$ & $4.95 \pm 3.26$ & $5.78 \pm 2.65$ & $7.68 \pm 3.40$ \\
\hline
\end{tabular}

* indicates the statistical significance, $p$-value $<0.05$ with the negative control by student's $t$-test

Effects of Crude Extract and MeOH Fraction on Blood Glucose Levels of Alloxan Induced Diabetic Mice

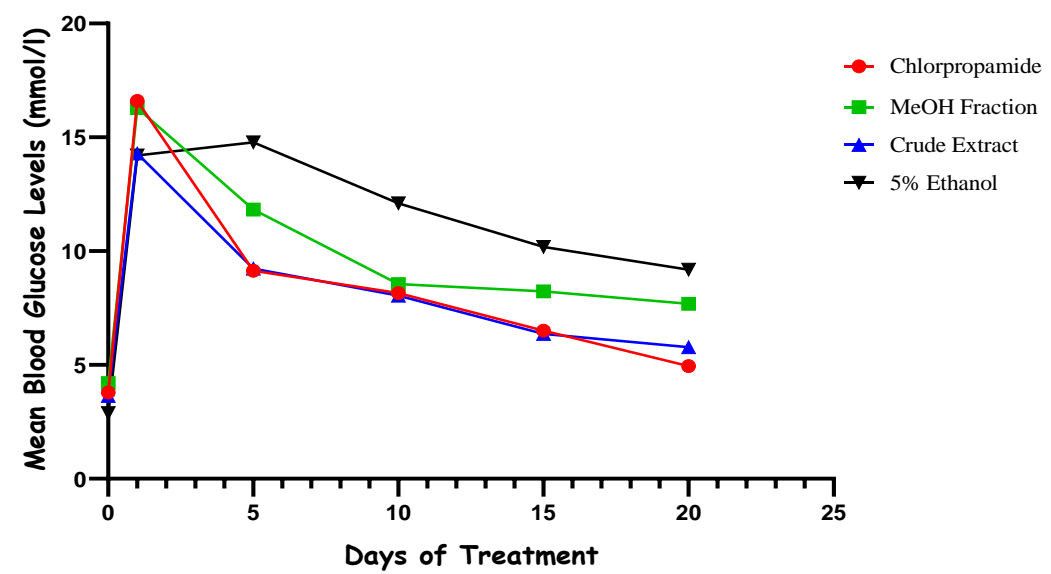

Figure1. Trend of Mean Blood Glucose levels during the treatment period

Percentage Decrease in Fasting Blood Glucose Levels in Alloxan Treated Diabetic Mice

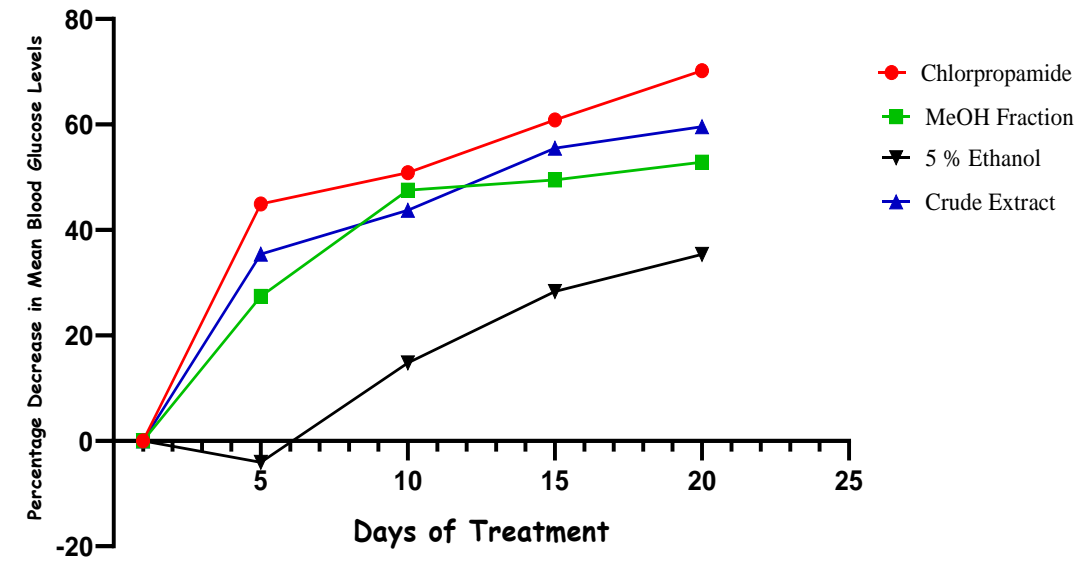

Figure2. Percentage decrease in mean blood glucose levels during the treatment period

Table2. Mean Body Weights of Alloxan Treated Mice

\begin{tabular}{|c|c|c|c|c|c|c|c|}
\hline \multirow[t]{2}{*}{ Groups } & \multicolumn{6}{|c|}{ Mean body weights \pm S.D $(g), n=8$} & \multirow{2}{*}{$\begin{array}{l}\% \\
\text { weight } \\
\text { decrease }\end{array}$} \\
\hline & Day 0 & Day 1 & \begin{tabular}{|l} 
Day 5 \\
\end{tabular} & Day 10 & Day 15 & Day 20 & \\
\hline $\begin{array}{lll}\text { Control } & - & 5 \% \\
\text { Ethanol } & & \\
\end{array}$ & $\begin{array}{ll}27.63 \quad \pm \\
3.78 & \\
\end{array}$ & $\begin{array}{ll}26.25 \quad \pm \\
4.03 & \\
\end{array}$ & \begin{tabular}{|l|}
24.75 \\
3.73 \\
\end{tabular} & $\begin{array}{l}24.25 \\
4.27 \\
\end{array}$ & $\begin{array}{l}24.13 \\
5.06\end{array}$ & $\begin{array}{l}23.00 \\
5.68 \\
\end{array}$ & $\begin{array}{l}16.75 \square \\
12.38 \ddagger\end{array}$ \\
\hline $\begin{array}{l}\text { Crude Extract } \\
100 \mathrm{mg} / \mathrm{kg} \mathrm{BW}\end{array}$ & $\begin{array}{ll}27.25 \quad \pm \\
1.83\end{array}$ & $\begin{array}{ll}27.13 \quad \pm \\
2.30\end{array}$ & $\begin{array}{l}26.00 \\
2.62\end{array}$ & $\begin{array}{ll}26.38 \quad \pm \\
2.67\end{array}$ & $\begin{array}{l}25.88 \\
3.52\end{array}$ & $\begin{array}{l}25.38 \\
3.85\end{array}$ & $\begin{array}{l}6.86 \square \\
6.45 \dagger\end{array}$ \\
\hline $\begin{array}{l}\text { Methanolic } \\
\text { Fraction } \\
100 \mathrm{mg} / \mathrm{kg} \mathrm{BW}\end{array}$ & $\begin{array}{ll}27.25 \quad \pm \\
2.43\end{array}$ & $\begin{array}{l}26.63 \\
2.92\end{array}$ & \begin{tabular}{|l|}
25.75 \\
3.96
\end{tabular} & $\begin{array}{l}26.63 \\
3.96\end{array}$ & $\begin{array}{l}26.38 \\
4.10\end{array}$ & $\begin{array}{l}25.75 \\
3.92\end{array}$ & $\begin{array}{l}5.50 \square \\
3.30 \ddagger\end{array}$ \\
\hline $\begin{array}{l}\text { Chlorpropamide } \\
\text { 100mg/kg BW }\end{array}$ & $\begin{array}{ll}24.63 \quad \pm \\
3.07 & \\
\end{array}$ & $\begin{array}{l}23.88 \\
3.94 \\
\end{array}$ & \begin{tabular}{|l|}
22.63 \\
4.44 \\
\end{tabular} & $\begin{array}{l}23.00 \\
4.47 \\
\end{array}$ & $\begin{array}{l}23.38 \\
4.34 \\
\end{array}$ & $\begin{array}{l}22.25 \\
3.58 \\
\end{array}$ & $\begin{array}{l}9.66 \square \\
6.82 \ddagger \\
\end{array}$ \\
\hline
\end{tabular}

Key: $\square \%$ in weight before alloxan administration (day 0); $\%$ in weight after alloxan administration (day 1) 


\section{ACUTE ORAL TOXICITY}

\section{General Observations}

No mortality was observed at the oral dose of $2000 \mathrm{mg} / \mathrm{kg}$ bodyweight of the crude ethanolic fruit extract of the plant to all mice exposed, as well as there were no abnormal change in behavioral properties of mice during all 14 days of observation. Organs morphology was normal in both control and treated groups. This indicates the $\mathrm{LD}_{50}$ of $S$. terminale ethanolic fruit extract is estimated to be above $2000 \mathrm{mg} / \mathrm{kg}$ bodyweight, which might be accepted to be safe according to the guideline [10].

Several plants have been reported to have different ranges of $\mathrm{LD}_{50}$, for example; Dahanukar et al (2000) reported and cited the $\mathrm{LD}_{50}$ of Vitexleucoxylonethanolic leaf extract to be above $3000 \mathrm{mg} / \mathrm{kg}$ body weight and Vitexleucoxyloncold water infusion extract to be $1050 \mathrm{mg} / \mathrm{kg}$ body weight on rats; Ailanthus excels ethanolic extracts at $1000 \mathrm{mg} / \mathrm{kg}$ body weight; Toddalia asiatica at $350 \mathrm{mg} / \mathrm{kg}$ body weight and $250 \mathrm{mg} / \mathrm{kg}$ body weight for Araucaria bidwilli[17]. Moringa oleifera ethanolic leaves extract have been revealed to have the oral $L_{50}$ value greater than $5000 \mathrm{mg} / \mathrm{kg}$ body weight, hence it is considered practically non-toxic which implies that the extract can be consumed at higher doses without fear of toxicity [18].

Acute oral toxicity studies of some other Solanum species have been reported, for example; the oral $\mathrm{LD}_{50}$ value of $S$. nigrum extract was estimated to be $3129 \mathrm{mg} / \mathrm{kg}$ body weight and regarded safe [19] whereas $S$. cernuum hydroalcoholic extract reported to have the oral $\mathrm{LD}_{50}$ value of $14.50 \mathrm{~g} / \mathrm{kg}$ bodyweight [20].

The OECD recommended the chemical labelling and classification of acute systemic toxicity of extracts and substances based on oral $\mathrm{LD}_{50}$ values being: very toxic, $<5 \mathrm{mg} / \mathrm{kg}$ body weight; toxic, $>5$ $<50 \mathrm{mg} / \mathrm{kg}$ body weight; harmful, $>50<500 \mathrm{mg} / \mathrm{kg}$ body weight; and no label, $>500<2000 \mathrm{mg} / \mathrm{kg}$ body weight [21]. To qualify being a drug candidate, the medicinal plant should possess no potential toxicity profile or should have low toxicity index, even after a long term use [22].

\section{Body Weight}

There were no significant variations observed in body weights of both treated and control mice groups in acute toxicity testing of the crude ethanolic extract. This indicates the possibility of the fruits not interfering with the feeding pattern of the mice.

Table3. Effects of Extract in Body weight of Mice in Acute Toxicity Testing

\begin{tabular}{|l|l|l|l|}
\hline \multirow{2}{*}{ Groups } & \multicolumn{3}{|l|}{ Mean body weights \pm S.D $(\mathbf{g}) \mathbf{n}=\mathbf{4}$} \\
\cline { 2 - 4 } & Day 1 & Day 7 & Day 14 \\
\hline Control - 5\% Ethanol & $27.4 \pm 1.1$ & $30.8 \pm 1.8$ & $30.8 \pm 1.6$ \\
\hline $\begin{array}{l}\text { Crude Extract } \\
\mathbf{2 0 0 0 m g / k g ~ B W}\end{array}$ & $28.0 \pm 1.4$ & $32.2 \pm 1.6$ & $31.8 \pm 1.1$ \\
\hline
\end{tabular}

\section{Organs Weight}

Some organs (liver, kidney, intestine, heart, spleen and lungs) were isolated from animals of both groups involved in the acute oral toxicity testing, and there were no any abnormal lesions observed. There were no significant variations in the measured mean organ weights observed as presented in the Table 4 and the percentage of organ to body weight index.

Organ to body weight index is one of key indicators in assessing potential harmful effects of plant extracts and fractions. The toxicity of extracts, fractions or any substance on the internal organs could be identified by assessing the relative organ weight as the index, giving a preliminary insight to the swelling or damage caused by any harmful agent [23]. Moreover, it has been considered that relative weights indices of internal organs reveal the extent of metabolic burden on the organ, mainly by its basic function [24].

Table4. Mean Organ Weights

\begin{tabular}{|c|c|c|c|c|c|}
\hline \multirow[t]{2}{*}{ Organs } & \multicolumn{2}{|c|}{ Mean organ weights \pm S.D $(g)$} & \multicolumn{2}{|c|}{ Organ to body weight index (\%) } & \multirow{2}{*}{$\begin{array}{c}\% \\
\text { Increase or } \\
\text { Decrease }\end{array}$} \\
\hline & $2000 \mathrm{mg} / \mathrm{kg} \mathrm{BW}$ & $5 \%$ Ethanol & $2000 \mathrm{mg} / \mathrm{kg} \mathrm{BW}$ & $5 \%$ Ethanol & \\
\hline Liver & $2.04 \pm 0.36$ & $1.70 \pm 0.5$ & 6.42 & 5.51 & $+0.91 \uparrow$ \\
\hline
\end{tabular}


In-Vivo Antidiabetic Activity and Safety Profile of Fruits Extract and Fraction of Solanum Terminale Forsk (Solanaceae)

\begin{tabular}{|c|c|c|c|c|c|}
\hline Heart & $0.14 \pm 0.01$ & $0.16 \pm 0.05$ & 0.45 & 0.52 & $-0.07 \downarrow$ \\
\hline Kidney & $0.55 \pm 0.07$ & $0.54 \pm 0.06$ & 1.72 & 1.75 & $-0.03 \downarrow$ \\
\hline Intestines & $2.54 \pm 0.37$ & $2.55 \pm 0.43$ & 7.97 & 8.28 & $-0.31 \downarrow$ \\
\hline Spleen & $0.28 \pm 0.12$ & $0.20 \pm 0.12$ & 0.88 & 0.66 & $+0.22 \uparrow$ \\
\hline Lungs & $0.22 \pm 0.02$ & $0.24 \pm 0.05$ & 0.70 & 0.78 & $-0.08 \downarrow$ \\
\hline
\end{tabular}

Key: $\downarrow=\%$ decrease, $\uparrow=\%$ increase, S.D $=$ standard deviation, $\mathrm{n}=4$

\section{HISTOPATHOLOGICAL EVALUATIONS}

The histopathological analysis revealed the normal organ structures in control animals. Slight/mild myocardial muscle degeneration was observed in the heart of treated mice groups as shown in Figure 3a.Stomach and intestines were normal, indicating no structure disorganization in the gastrointestinal tract after extract oral administration. Mild congestion in capillary glomerulus and thrombosis was seen in the kidney of the treated mice groups as shown in Figure 3b; persistence of this condition is life threatening that may lead to kidney injury and other clinical manifestations [25]. Mild focal inflammatory reactions of the liver were also observed in the treated mice shown in Figure 4a as steatosis which occurs due to toxic stress [26].

Red pulp hyperplasia of the spleen was observed in the treated mice as presented in Figure $\mathbf{4 b}$ which is described as malformation since spleen is the primary target indicating the direct and indirect toxicity of various agents [27]. Therefore, loss of the intact organization in the spleen could be associated with administered $S$. terminale crude fruits ethanolic extract demonstrating potential toxicity effect of the extract at higher doses.
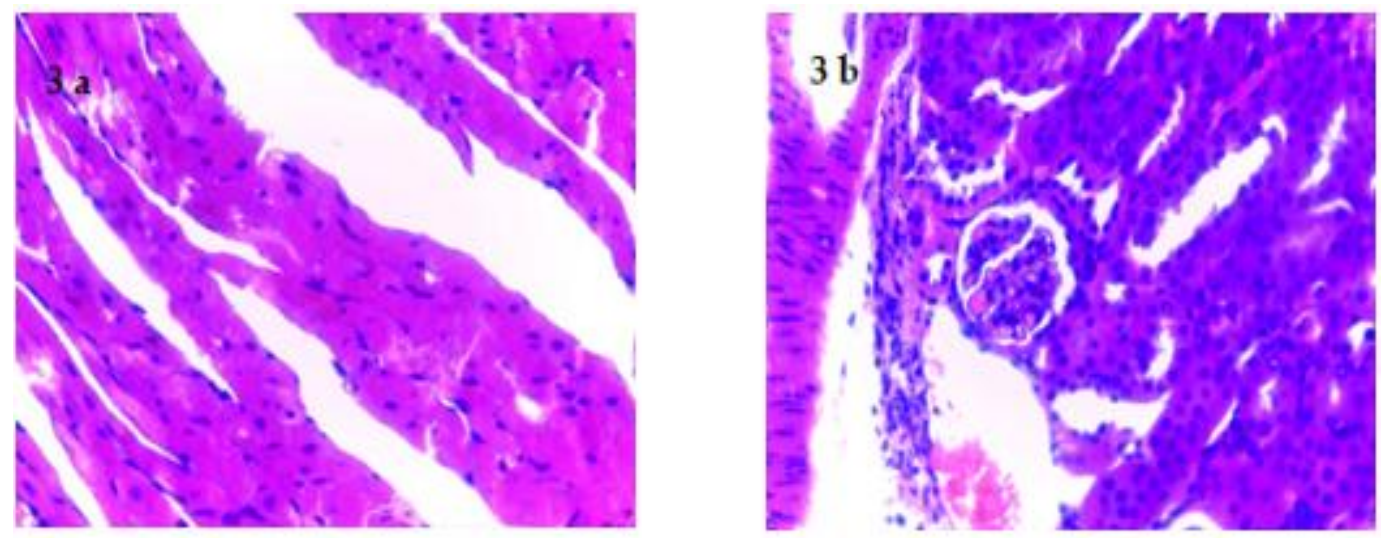

Figure3. Photomicrographs indicating myocardial muscle degeneration of heart (3a) and congestion in glomerulus and capillary thrombosis $(3 b)$ of the kidney
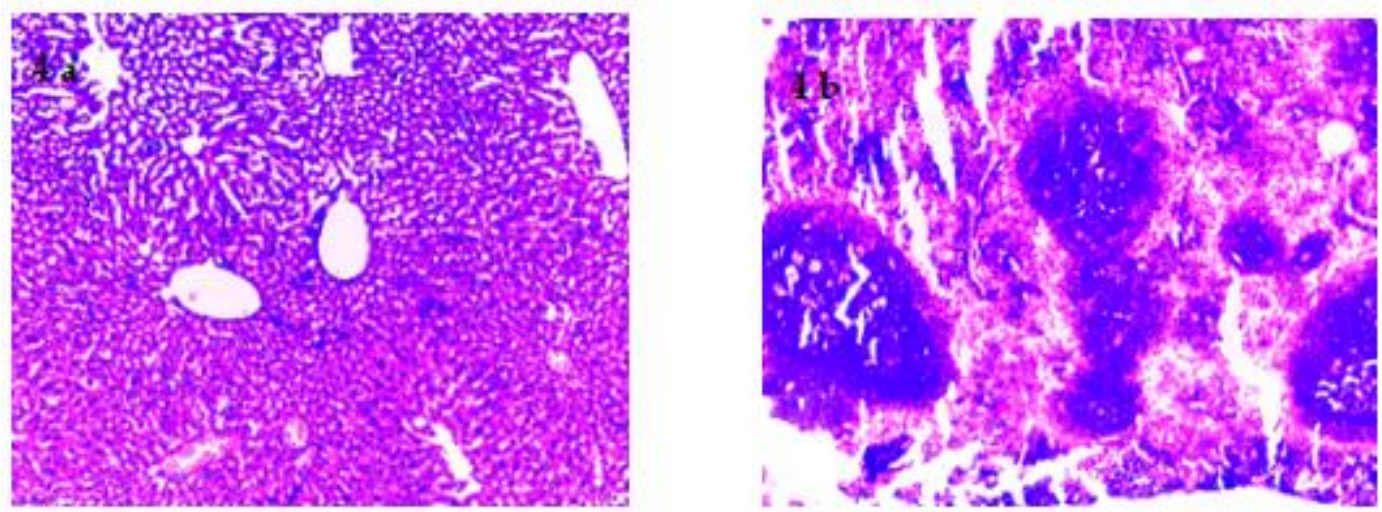

Figure4. Photomicrographs showing mild focal lymphatic infiltrates in the liver (4a) and Red pulp expansion and disorganization of white pulps of the spleen $(4 b)$

\section{CONCLUSION}

The results of this study indicate the potential of the fruits in diabetes management. The ethanolic extract gave the best results suggesting high probability of polar and less polar compounds working in a synergistic manner in the reduction of blood glucose levels. 
The observed antidiabetic dose of the crude ethanolic extract is far much low compared to the toxic dose tested. Nevertheless, cautions should be put in place when usingthesefruits for medicinal purposes most especiallyin older age individuals with probable compromised health conditions.

Authors suggests further studies to be conducted for the plant fruits (i) To carry out various in vivo and in vitro techniques to confirm the antidiabetic activities and mechanism of action (ii) To carry out more toxicological studies such as, sub chronic and chronic toxicity, genotoxicity, embryo toxicity, haematological toxicity etc., so as to ascertain the safety status of $S$. terminale fruits (iii) To identify and isolate the most active compounds (iv) To standardize and, (v) To formulate $S$. terminale fruits herbal products to facilitate availability even during the off season and ease of distribution to the consumers.

\section{ACKNOWLEDGEMENTS}

Authors are grateful to Prof. Luc Pieters from the Department of Pharmaceutical Sciences, the University of Antwerp, Belgium, for donating Alloxan monohydrate that was essential for obtaining conclusive results of antidiabetic activity. The University of Dodoma, for financial supports during the study leave.

\section{REFERENCES}

[1] Mukundi MJ, Mwaniki NEN, Piero NM, Murugi NJ, Daniel AS, Peter GK, et al. In Vivo Anti-diabetic Effects of Aqueous Leaf Extracts of Rhoicissus tridentata in Alloxan Induced Diabetic Mice. J Dev Drugs. 2015;04(03).

[2] Arika WM, Nyamai DW, Agyirifo DS, Ngugi MP, Njagi ENM. In Vivo Antidiabetic Effect of Aqueous Leaf Extract of Azardirachta indica, A. juss in Alloxan Induced Diabetic Mice. J Diabet Complicat Med. 2016;1(2):1-6.

[3] Muntean E, Michalski R, Muntean N, Duda M. Chemical Risk Due To Heavy Metal Contamination Of Medicinal Plants. Hop Med Plants. 2016;24(1):71-8.

[4] Osadebe P, Odoh E, Uzor P. Natural Products as Potential Sources of Antidiabetic Drugs. Br J Pharm Res. 2014;4(17):2075-95.

[5] Day C, Bailey CJ. Traditional Herbal Medicines for Modern Times - Antidiabetic Plants. Soumyanath A, editor. New York: Taylor \& Francis Group; 2006. 83-98 p.

[6] Kingo RM, Maregesi SM, Kidukuli AW. Hypoglycaemic efficacy and phytochemical screening of fruits ethanolic extract of solanum terminale forsk (solanaceae). Issues Biol Sci Pharm Res. 2020;8(2):37-42.

[7] Ighodaro OM, Adeosun AM, Akinloye OA. Alloxan-induced diabetes, a common model for evaluating the glycemic-control potential of therapeutic compounds and plants extracts in experimental studies. Med. 2017;53(6):365-74.

[8] Ma L, Zhang S, Du M. Cordycepin from Cordyceps militaris prevents hyperglycemia in alloxan-induced diabetic mice. Nutr Res. 2015;35(5):431-9.

[9] Tafesse TB, Hymete A, Mekonnen Y, Tadesse M. Antidiabetic activity and phytochemical screening of extracts of the leaves of Ajuga remota Benth on alloxan-induced diabetic mice. BMC Complement Altern Med. 2017;17(1):1-9.

[10] Organization for Economic Co-operation and Development. Acute Oral Toxicity - Acute Toxic Class Method 423. OECD Guidel Test Chem. 2001;(December):1-14.

[11] Dammeyer P, Mwakigonja AR, Rethi B, Chiodi F, Wolpert EZ. Vaccination with $\beta 2$-microglobulindeficient dendritic cells protects against growth of $\beta 2$-microglobulin-deficient tumours. Scand J Immunol. 2009;70(1):44-52.

[12] Mwakigonja A, Pak F, Kaaya E, Pyakurel P, Urassa W, Mosha I, et al. Oral Kaposi's sarcoma in Tanzania: Presentation, immunopathology and human herpesvirus-8 association. Oncol Rep. 2007;17:1291-9.

[13] EEC. Council Directive 86/609 EEC for the protection of animals used for experimental and other scientific purposes. Off J. 1986;L358(L):1-28.

[14] CPCSEA. CPCSEA Guidelines for Laboratory Animal Facility. Indian J Pharmacol. 2003;35(13):257274.

[15] Moshi MJ, Uiso FC, Mahunnah RLA, Malele SR, Swai ABM. A Study of the Effect of Phyllanthus Amarus Extracts on Blood Glucose in Rabbits. Int J Pharmacogn. 1997;35(3):167-73.

[16] Badole SL, Shah SN, Patel NM, Thakurdesai PA, Bodhankar SL. Hypoglycemic activity of aqueous extract of Pleurotus pulmonarius in alloxan-induced diabetic mice. Pharm Biol. 2006;44(6):421-5. 
[17] Dahanukar SA, Kulkarni RA, Rege NN. Pharmacology of medicinal plants and natural products. Indian J Pharmacol. 2000;32:S81-118.

[18] Idakwoji PA, Salawu OA, Maiha BB, Obidike I, Tijani AY. Co-administeration of Ethanolic Leaf Extract of Moringa oleifera and Metformin Improves Glucose, Lipid and Protein Profiles of Diabetic Wistar rats. Biokemistri. 2015;27(3):123-38.

[19] Son LH, Yen PTH. Preliminary phytochemical screening, acute oral toxicity and anticonvulsant activity of the berries of Solanum nigrum Linn. Trop J Pharm Res. 2014;13(6):907-12.

[20] Almanca CCJ, Saldanha S V., Sousa DR, Trivilin LO, Nunes LC, Porfírio LC, et al. Toxicological evaluation of acute and sub-chronic ingestion of hydroalcoholic extract of Solanum cernuum Vell. in mice. J Ethnopharmacol. 2011;138(2):508-12.

[21] Walum E. Acute oral toxicity. Environ Health Perspect. 1998;106(2):497-503.

[22] Saleem U, Amin S, Ahmad B, Azeem H, Anwar F, Mary S. Acute oral toxicity evaluation of aqueous ethanolic extract of Saccharum munja Roxb. roots in albino mice as per OECD 425 TG. Toxicol Reports. 2017;4(October):580-5.

[23] Pariyani R, Safinar II, Azam AA, Abas F, Shaari K, Sulaiman MR. Phytochemical Screening and Acute Oral Toxicity Study of Java Tea Leaf Extracts. Biomed Res Int. 2015;2015:1-8.

[24] Liro A. Variation in weights of body and internal organs of the field mouse in a gradient of urban habitats. Acta Theriol (Warsz). 1985;30:359-77.

[25] Navarro D, Ferreira AC, Viana H, Carvalho F, Nolasco F. Cavernous sinus thrombosis in a patient with nephrotic syndrome. CEN Case Reports. 2017;6(2):136-9.

[26] Koyama Y, Brenner DA. Liver inflammation and fibrosis. J Clin Invest. 2017;127(1):55-64.

[27] Suttie AB. Pathology of the spleen. Vol. 34, Toxicologic Pathology. 2006. 466-503 p.

Citation: Rajabu M. Kingo, et.al., (2020). "In-Vivo Antidiabetic Activity and Safety Profile of Fruits Extract and Fraction of Solanum Terminale Forsk (Solanaceae)". International Journal of Medicinal Plants and Natural Products (IJMPNP), 6(2), pp.14-22. http://dx.doi.org/ 10.20431 /2454-7999.0602003

Copyright: (C) 2020 Authors. This is an open-access article distributed under the terms of the Creative Commons Attribution License, which permits unrestricted use, distribution, and reproduction in any medium, provided the original author and source are credited. 